\title{
Bacterial Community Composition of Sapanca Lake During a Cyanobacterial Bloom
}

\author{
E. Gözde Özbayram ${ }^{1}$ (D), Latife Köker ${ }^{1}$ (D), Reyhan Akçaalan ${ }^{1}$ (D), Orhan İnce ${ }^{2}$ (D), Meriç Albay ${ }^{1}$ (D)
}

Cite this article as: Özbayram, E. G., Köker, L., Akçaalan, R., Ince, O., Albay, M. (2020). Bacterial community composition of sapanca lake during a cyanobacterial bloom. Aquatic Sciences and Engineering, 35(2), 52-56.

ORCID IDs of the authors: E.G.O. 0000-0002-5416-0611; L.K. 0000-0002-9134-2801;

R.A. 0000-0002-0756-8972; O.I. 0000-0001-5028-8872; M.A. $0000-0001-9726-945 \mathrm{X}$

1Istanbul University, Faculty of Aquatic Sciences, Department of Marine and Freshwater Resources Management, Istanbul, Turkey

${ }^{2}$ Istanbul Technical University, Faculty of Civil Engineering, Department of Environmental Engineering, Istanbul, Turkey

\section{Submitted:}

28.11.2019

Revision Requested: 17.01.2020

Last Revision Received: 20.01.2020

\section{Accepted:}

21.01.2020

Correspondence:

E. Gözde Özbayram

E-mail:

gozde.ozbayram@istanbul.edu.tr

(C) Copyright 2020 by Aquatic

Sciences and Engineering

Available online at

https://dergipark.org.tr/ase

\begin{abstract}
Microbial community compositions and functions of freshwater ecosystems vary due to the environmental parameters and water chemistry. Transient bloom events play a crucial role on the community profiles. In this study, a specific focus was set to provide a snapshot of the bacterial community composition in Lake Sapanca, associated with cyanobacterial bloom by high throughput sequencing method. For this purpose, a sample was collected in the shore of Lake Sapanca during a cyanobacterial bloom, and the bacterial community profile was examined by $16 \mathrm{~S}$ rRNA amplicon sequencing using the Illumina MiSeq platform. Cyanobacteria represented $94 \%$ of the all reads. The bacterial community was re-calculated to evaluate the bacterial diversity in detail by filtering cyanobacterial sequences. The community was dominated by Proteobacteria (44\%) and Bacteroidetes (33\%) species which are abundant in freshwater ecosystems having an ability to degrade complex organics. Among the classified genera, Flavobacterium and Rheinheimera dominated the bacterial community suggesting a strong link between those species and the cyanobacterial bloom. The experimental work presented here provides one of the first investigations of total bacterial communities in Lake Sapanca by the high throughput sequencing method. Further work is needed with more sampling points and time series to fully understand the bacterial diversity and dynamics.
\end{abstract}

Keywords: Bacterial community, cyanobacterial bloom, illumina miseq, Sapanca lake, 16S rRNA

\section{INTRODUCTION}

Freshwater habitats have a vital role in global biogeochemical cycles. However, cyanobacterial blooms are getting more widespread in freshwater lakes due to nutrient runoff and climate change, and have become a serious risk on the sustainability of these ecosystems (Cai et al., 2014; Liu et al., 2019) which cause difficulties to secure and maintain ecosystem health (Woodhouse et al., 2016).

Microorganisms drive crucial functions in the freshwater ecosystems and have a role in the degradation of organic materials, energy conversion and nutrient recycling, overall contrib- ute to the ecosystem balance (Su et al., 2017a; Zhu et al., 2019). Microbial community compositions and functions vary due to the water chemistry, nutrient concentrations, hydrodynamic stability and climate (Steffen et al., 2012), and they respond to environmental alterations quickly being critical indicators (Su et al., 2017b). Furthermore, community structures are highly dependent on transient bloom events which affect the abundance and activity of these communities (Eiler \& Bertilsson, 2004). Since microbial communities are key players on biogeochemical cycles, there is still limited information on the characterization and function of bacterial communities inhabiting freshwater 
ecosystems, especially during bloom events (Eiler \& Bertilsson, 2004; Steffen et al., 2012).

Recent developments in advanced molecular genetic technologies enable us to have deep information about microbial diversity and interactions between the community structure and their environment (Nakatsu, Byappanahalli, \& Nevers, 2019). Since the $16 \mathrm{~S}$ rRNA gene is considered as a molecular marker of prokaryotes and used to investigate microbial communities in a wide variety of habitats, it has also been used to asses microbial community dynamics during cyanobacterial blooms (Nakatsu et al., 2019; Zhu et al., 2019).

Lake Sapanca, a freshwater lake, is located in the northeast of the Marmara Region of Turkey. It is a source for drinking water for the cities of Sakarya and Kocaeli, as well as for industrial usage (Akçaalan et al., 2014; Leroy \& Albay, 2010), and has been monitored according to the presence of cyanobacteria and cyanotoxin for years to indicate the ecological status of the lake, and it has now a well-established cyanobacteria diversity (Akçaalan et al., 2007; Akçaalan et al., 2014). Moreover, there are some studies in the literature on Lake Sapanca which evaluated the total bacterial counts, pathogenic bacteria and petroleum-resistant bacteria presence by a culture dependent technique (Altuğ et al. 2006; Çiftçi Türetken et al., 2018), and seasonal dynamics of pathogens by the microarray method (Akçaalan et al., 2018). So far, there have been no attempts to examine the total bacterial community structure in Lake Sapanca, and it has remained unclear. This study, therefore, sets out to assess the bacterial community composition in Lake Sapanca during a cyanobacterial bloom by the high throughput sequencing method. The experimental work presented here provides one of the first investigations into the bacterial community profile of Lake Sapanca by a next generation sequencing platform.

\section{MATERIALS AND METHODS}

\section{Physico-chemical characterization}

A surface cyanobacterial bloom occurred in Lake Sapanca on 8 April, 2019 and the sample was collected during the bloom event in the shore. $\mathrm{pH}$, temperature and dissolved oxygen were measured with a portable multiparameter (6600, YSI, USA) on the sampling date.

\section{DNA extraction and amplicon sequencing}

First, $10 \mathrm{~mL}$ the sample was filtered with a $0.22 \mu \mathrm{m}$ filter, and total DNA was extracted from that filter paper using a MoBio PowerWater ${ }^{\circledR}$ DNA Isolation Kit (MoBio Laboratories, Inc., CA, USA) according to the manufacturer's protocol. The DNA quantification was performed by NanoDrop 1000 (Thermo Fisher Scientific, Inc., DE, USA), and the extracted DNA was stored at $-20^{\circ} \mathrm{C}$ for further analysis.

The bacterial community composition of the sample was analyzed with the ZymoBIOMICS TM Service - Targeted Amplicon Sequencing (Zymo Research, Irvine, CA). 16S ribosomal RNA gene targeted sequencing was performed using the Quick-16S TM NGS Library Preparation Kit (Zymo Research, Irvine, CA). Shortly, the $16 \mathrm{~S}$ primers used amplified the V3-V4 region of the 16S rRNA gene (341f-CCTACGGGNGGCWGCAG and 805r-GACTACHVG-
GGTATCTAATCC). The $\mathrm{PCR}$ products were quantified with $\mathrm{qPCR}$ fluorescence readings, and pooled together based on equal molarity. The final pooled library was cleaned up with Select-a-Size DNA Clean \& Concentrator TM (Zymo Research, Irvine, CA), then quantified with TapeStation $\AA$ and Qubit $\Theta$. The final library was sequenced on Illumina ${ }^{\circledR}$ MiSeq $^{\text {TM }}$ with a v3 reagent kit (600 cycles). The sequencing was performed with $>10 \% \mathrm{PhiX}$ mix and in paired-end mode.

The Dada2 pipeline was used to infer the amplicon sequences from raw reads (Callahan et al., 2016). The raw sequence reads were trimmed with Trimmomatic-0.33 (Bolger, Lohse, \& Usadel, 2014). Whereas, SeqPrep were used to assemble the two pairedend reads to have a complete amplicon sequence with (https:// github.com/jstjohn/SeqPrep). Usearch (v. 6.1) was used to check and remove chimeric amplicon sequences (Edgar, 2010) in ref mode against a curated database (http://drive5.com/uchime/ rdp_gold.fa). Amplicon sequences smaller than 320 bp were removed. For each sample, up to 40,000 sequences were randomly sampled to reduce the potential bias caused by uneven sampling. These amplicon sequences were compiled, clustered and analyzed with Qiime 1.9.1 (Caporaso et al., 2010). OTUs were picked by the workflow of pick_open_reference_otus.py using the GreenGene database (9g_13_8) as reference database. Singleton OTUs were removed. Taxonomy assignment was performed with Qiime v.1.9.1 (Caporaso et al., 2010). The microbial community structures were shown by Krona graphs (Ondov, Bergman, \& Phillippy, 2011; Ozbayram et al., 2017).

\section{RESULTS AND DISCUSSION}

The physical properties of Lake Sapanca during the bloom are depicted in Table 1. The water was slightly alkaline and the characteristics of the lake matched those observed in early studies (Akçaalan et al., 2007, 2014) showing a typical $\mathrm{O}_{2}$ saturation level during the bloom event with high dissolved oxygen.

Table 1. Physical properties of Lake Sapanca during the cyanobacterial bloom

\begin{tabular}{cc}
\hline Parameter & Lake Sapanca \\
Temperature $\left({ }^{\circ} \mathrm{C}\right)$ & 15.9 \\
$\mathrm{pH}$ & 8.51 \\
Conductivity $(\mathrm{uS} / \mathrm{cm})$ & 215.6 \\
Dissolved Oxygen $(\mathrm{mg} / \mathrm{L})$ & 13.57 \\
$\mathrm{O}_{2}$ Saturation $(\%)$ & 130.3
\end{tabular}

The number of raw reads and after filtration were 78,735 and 65,748 , respectively and the rarefaction curve reached a plateau. The microbial community composition of the bloom sample was presented at multiple taxonomic levels by a Krona chart in Figure 1. The microbial community comprised 7 phyla, however, the microbial community was dominated by Cyanobacteria members, representing $94 \%$ of all sequences as it was expected. At the genus level, all of the Cyanobacteria reads belonged to Planktothrix. The results are in keeping with previous observational studies, 
which showed that the cyanobacterial bloom was mainly caused by Planktothrix rubescens in Lake Sapanca (Akçaalan et al., 2007, 2014). Proteobacteria and Bacteroidetes were the following phyla, representing $5 \%$ of the microbial community. The results are in agreement with those of previous studies, indicating that the bacterial community was dominated by Proteobacteria, Actinobacteria, and Bacteriodetes during the phytoplankton bloom (Berg et al., 2009; Eiler, Bertilsson, \& Centre, 2007; Zhu et al., 2019).

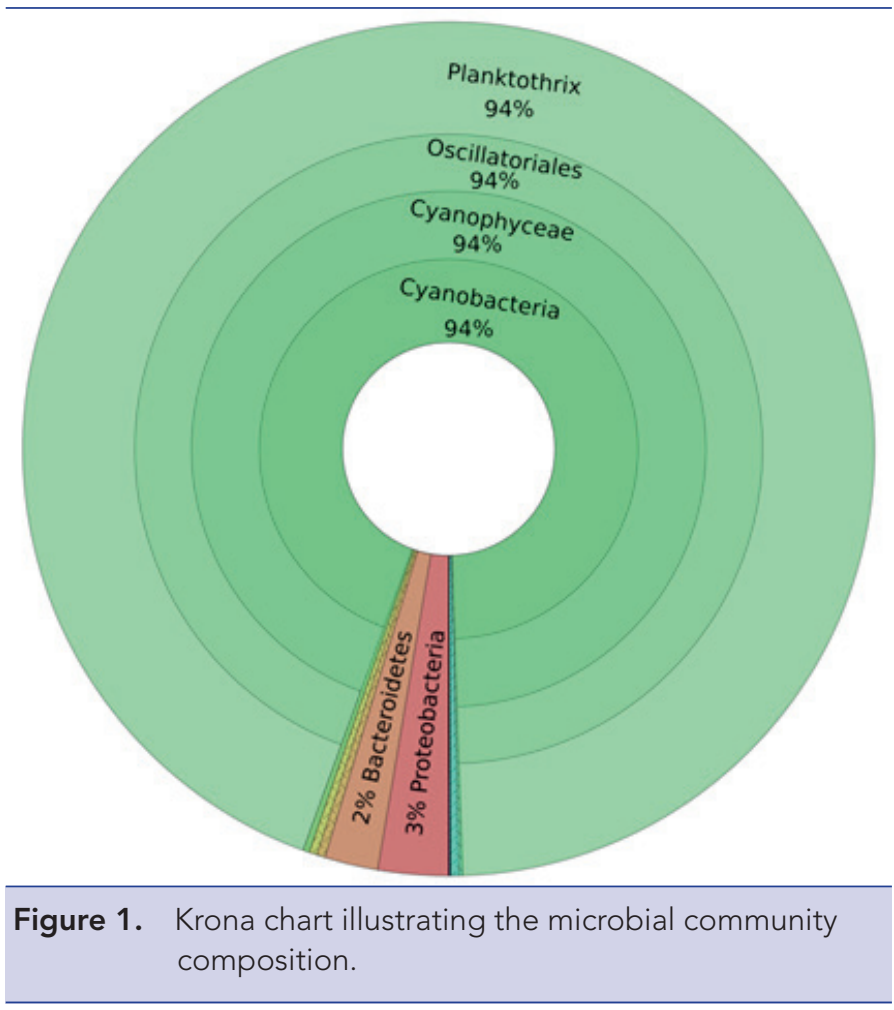

To understand the microbial community diversity better, the bacterial reads were evaluated excluding Cyanobacterial sequences, and re-calculated relative abundances of the bacterial community are depicted in Figure 2. As it is clear from the chart, more than half of the reads were represented by Proteobacteria (44\%) and Bacteroidetes (33\%). Actinobacteria was the third dominant phylum, representing only $5 \%$ of the bacterial community, followed by Planctomycetes (5.3\%), Verrucomicrobia (5\%) and Gemmatimonadetes. Proteobacteria and Bacteroidetes have the ability to become abundant in the presence of bioavailable organic material, and dominate the community (Eiler et al., 2007). The members are known to be able to decompose complex organic materials, and the peptides of the organic carbon plays a crucial role with their $A B C$ membrane transporters which may support toxin degradation (Lezcano et al., 2017).

Within Proteobacteria, Betaproteobacteria was the dominant class, representing almost half of the total reads in Proteobacteria, followed by Gammaproteobacteria and Alphaproteobacteria. Betaproteobacteria was found as abundant in freshwater ecosystems (Zhu et al., 2019). Flavobacteriia (29\%) was the domi- nant class within Bacteroidetes, and showed a relatively high abundance compared to Sphingobacteriia (2\%) and Cytophagia (2\%). Most of the Flavobacteriia members are chemoorganotrophs, and are able to use complex organic materials as a carbon source (Parulekar et al., 2017). In terms of family level, $25 \%$ of the bacterial community was represented by Flavobacteriaceae (phylum: Bacteroidetes), which was by far the most abundant among all the families. Comamonadaceae (phylum: Proteobacteria) was the second most abundant family, representing $14 \%$ of the total reads. Moreover, $9 \%$ of the bacterial community was assigned to Chromatiaceae (phylum: Proteobacteria). The families Burkholderiaceae, Sphingomonadaceae, Pseudomonadaceae, Cryomorphaceae and Phycisphaeraceae together represented $18 \%$ of the bacterial community.

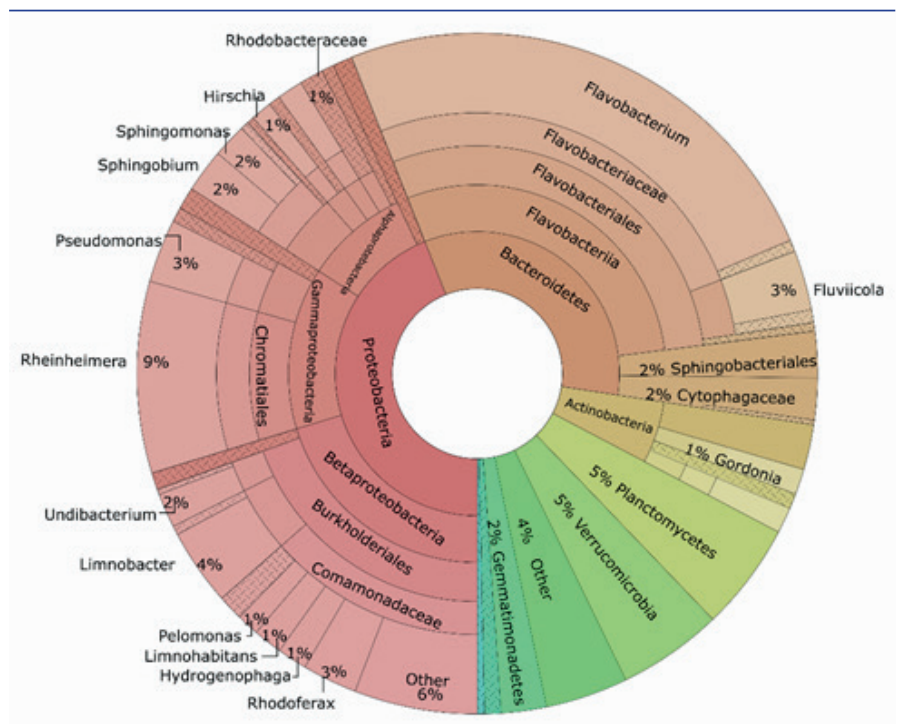

Figure 2. Krona chart illustrating the bacterial community composition (excluding Cyanobacteria).

The overgrowth of Cyanobacterial species causes bacterial community changes with an increasing abundances of the members which have an ability to decompose organic matter and toxic compounds (Lezcano et al., 2017; Su et al., 2017b). Thus, it is expected to observe Bacteroidetes members in high abundance during the phytoplankton blooms (Eiler et al., 2007). Among the classified genera, Flavobacterium (phylum: Bacteroidetes) dominated the bacterial community, accounting for $25 \%$ of the total sequences (Figure 3). The high abundance suggests that a strong link may exist between the bloom and Flavobacterium species which can degrade various biomacromolecules and carbohydrates. The members can react to transient nutrient loads immediately, which is a result of phytoplankton blooms (Buchan, LeCleir, Gulvik, \& González, 2014). Whereas some of Flavobacterium species have a potential to degrade cyanotoxin, some of them are reported to have a role in denitrification (Parulekar et al., 2017). Rheinheimera was the second most dominant genus, representing $9 \%$ of the bacterial community. Rheinheimera has also higher abundances in the aquatic environments and can hy- 


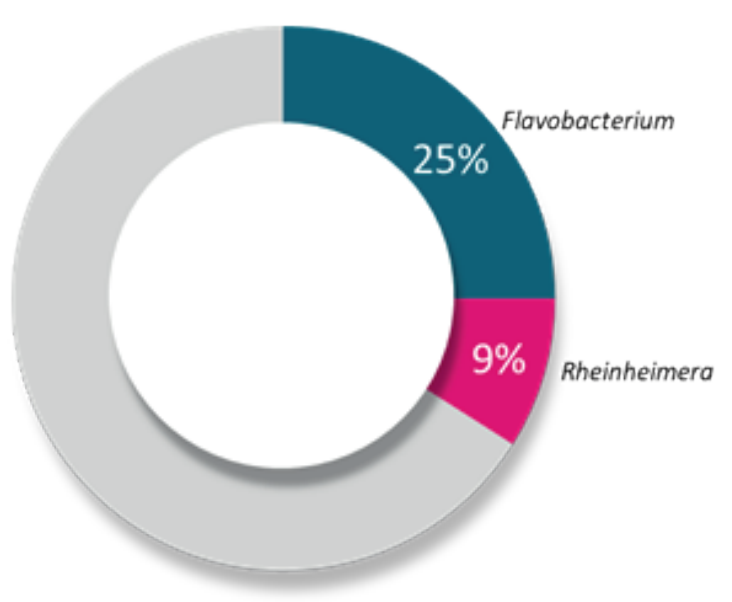

Figure 3. The dominant bacterial genera representing more than $5 \%$ of the all sequences are shown in colors.

The grey part represented the rest of the bacterial genera which represented $<5 \%$ of the all sequences.

drolyze organic materials. It is speculated that, Rheinheimera species can regulate phosphate exchange in the cyanobacterial mucilage capsule resulting in the enhancement of Microcystis growth (Parulekar et al., 2017).

\section{CONCLUSION}

The present research explores, for the first time, the bacterial communities associated with cyanobacterial blooms in Lake Sapanca by $16 \mathrm{~S}$ rRNA targeted amplicon sequencing. This study has shown that the bacterial community was dominated by bloom-associated phyla, Proteobacteria and Bacteroidetes, having the ability to grow on complex organic materials.

These findings provide a snapshot of the bacterial communities in Lake Sapanca during the cyanobacterial bloom. Further work is needed, with more sampling, to fully understand the bacterial diversity and dynamics.

Conflict of Interest: The author has no conflicts of interest to declare.

Ethics Committee Approval: Ethics committee approval is not required.

Financial Disclosure: The authors declared that this study received no financial support.

\section{REFERENCES}

Akçaalan, R., Albay, M., Gürevin, C., \& Çevik, F. (2007). The influence of environmental conditions on the morphological variability of phytoplankton in an oligo-mesotrophic Turkish lake. Annales de Limnologie - International Journal of Limnology, 43(1), 21-28. [CrossRef]

Akçaalan, R., Albay, M., Koker, L., Baudart, J., Guillebault, D., Fischer, S., Medlin, L. K. (2018). Seasonal dynamics of freshwater pathogens as measured by microarray at Lake Sapanca, a drinking water source in the north-eastern part of Turkey. Environmental Monitoring and Assessment, 190(1). [CrossRef]
Akçaalan, R., Köker, L., Gürevin, C., \& Albay, M. (2014). Planktothrix rubescens: A perennial presence and toxicity in Lake Sapanca. Turkish Journal of Botany, 38(4), 782-789. [CrossRef]

Altuğ, G., Yardimci, C. H., Okgerman, H., \& Tarkan, S. A. (2006). Levels of Bacterial Metabolic Activity, Indicator (Coliform, Escherichia coli) and Pathogen Bacteria (Salmonella spp.) in the Surface Water of Sapanca Lake, Turkey. Journal of Black Sea / Mediterranean Environment, 12(1), 67-77

Berg, K. A., Lyra, C., Sivonen, K., Paulin, L., Suomalainen, S., Tuomi, P., \& Rapala, J. (2009). High diversity of cultivable heterotrophic bacteria in association with cyanobacterial water blooms. ISME Journal, 3(3), 314-325. [CrossRef]

Bolger, A. M., Lohse, M., \& Usadel, B. (2014). Trimmomatic: A flexible trimmer for Illumina sequence data. Bioinformatics, 30(15), 2114 2120. [CrossRef]

Buchan, A., LeCleir, G. R., Gulvik, C. A., \& González, J. M. (2014). Master recyclers: features and functions of bacteria associated with phytoplankton blooms. Nature Reviews. Microbiology, 12(10), 686698. [CrossRef]

Cai, H., Jiang, H., Krumholz, L. R., \& Yang, Z. (2014). Bacterial community composition of size-fractioned aggregates within the phycosphere of cyanobacterial blooms in a eutrophic freshwater lake. PLOS ONE, 9(8). [CrossRef]

Callahan, B. J., McMurdie, P. J., Rosen, M. J., Han, A. W., Johnson, A. J. A., \& Holmes, S. P. (2016). DADA2: High-resolution sample inference from Illumina amplicon data. Nature Methods, 13(7), 581-583. [CrossRef]

Caporaso, J. G., Kuczynski, J., Stombaugh, J., Bittinger, K., Bushman, F. D., Costello, E. K., Knight, R. (2010). QlIME allows analysis of highthroughput community sequencing data. Nature Methods, 7(5), 335336. [CrossRef]

Çiftçi Türetken, P., Altuğ, G., Çardak, M., \& Güneş, K. (2018). Sapanca Gölü'nden İzole Edilen Bakteri Suşlarının Petrol Hidrokarbonlarını Parçalama Yetenekleri. Kahramanmaraş Sütçü Imam Üniversitesi Doğa Bilimleri Dergisi, 21(4), 535-544. [CrossRef]

Edgar, R. C. (2010). Supplementary Material - Search and clustering orders of magnitude faster than BLAST. Bioinformatics, 26(19), 2460 2461. [CrossRef]

Eiler, A., \& Bertilsson, S. (2004). Composition of freshwater bacterial communities associated with cyanobacterial blooms in four Swedish lakes. Environmental Microbiology, 6(12), 1228-1243. [CrossRef]

Eiler, A., Bertilsson, S., \& Centre, E. B. (2007). Flavobacteria Blooms in Four Eutrophic Lakes: Linking Population Dynamics of Freshwater Bacterioplankton to Resource Availability †, 73(11), 3511-3518. [CrossRef]

Leroy, S. A. G., \& Albay, M. (2010). Palynomorphs of brackish and marine species in cores from the freshwater Lake Sapanca, NW Turkey. Review of Palaeobotany and Palynology, 160(3-4), 181-188. [CrossRef]

Lezcano, M. A., Velazquez, D., Quesada, A., \& El-shehawy, R. (2017). Diversity and temporal shifts of the bacterial community associated with a toxic cyanobacterial bloom : An interplay between microcystin producers and degraders. Water Research, 125, 52-61. [CrossRef]

Liu, M., Liu, L., Chen, H., Yu, Z., Yang, J. R., Xue, Y., Huang, B., Yang, J. (2019). Community dynamics of free-living and particle-attached bacteria following a reservoir Microcystis bloom. Science of the Total Environment, 660, 501-511. [CrossRef]

Nakatsu, C. H., Byappanahalli, M. N., \& Nevers, M. B. (2019). Bacterial Community 16S rRNA Gene Sequencing Characterizes Riverine Microbial Impact on Lake Michigan, 10(May), 1-12. [CrossRef]

Ondov, B. D., Bergman, N. H., \& Phillippy, A. M. (2011). Interactive metagenomic visualization in a Web browser. BMC Bioinformatics, 12(1), 385. [CrossRef] 
Ozbayram, E. G., Kleinsteuber, S., Nikolausz, M., Ince, B., \& Ince, O. (2017). Effect of bioaugmentation by cellulolytic bacteria enriched from sheep rumen on methane production from wheat straw. Anaerobe, 46, 122-130. [CrossRef]

Parulekar, N. N., Kolekar, P., Jenkins, A., Kleiven, S., Utkilen, H., Johansen, A., Sæb, M. (2017). Characterization of bacterial community associated with phytoplankton bloom in a eutrophic lake in South Norway using 16S rRNA gene amplicon sequence analysis, 1-22. [CrossRef]

Steffen, M. M., Li, Z., Effler, T. C., Hauser, L. J., Boyer, G. L., \& Wilhelm, S. W. (2012). Comparative Metagenomics of Toxic Freshwater Cyanobacteria Bloom Communities on Two Continents. PLoS ONE, 7(8), 1-9. [CrossRef]
Su, X., Steinman, A. D., Tang, X., Xue, Q., Zhao, Y., \& Xie, L. (2017a). Response of bacterial communities to cyanobacterial harmful algal blooms in Lake Taihu, China. Harmful Algae, 68, 168-177. [CrossRef]

Su, X., Steinman, A. D., Tang, X., Xue, Q., Zhao, Y., \& Xie, L. (2017b). Response of bacterial communities to cyanobacterial harmful algal blooms in Lake Taihu, China. Harmful Algae, 68, 168-177. [CrossRef] Woodhouse, J. N., Kinsela, A. S., Collins, R. N., Bowling, L. C., Honeyman, G. L., Holliday, J. K., \& Neilan, B. A. (2016). Microbial communities reflect temporal changes in cyanobacterial composition in a shallow ephemeral freshwater lake. ISME Journal, 10(6), 1337-1351. [CrossRef]

Zhu, C., Zhang, J., Nawaz, M. Z., Mahboob, S., Al-Ghanim, K. A., Khan, I. A., Chen, T. (2019). Seasonal succession and spatial distribution of bacterial community structure in a eutrophic freshwater Lake, Lake Taihu. Science of the Total Environment, 669, 29-40. [CrossRef] 